УДК 338.48

\title{
ІННОВАЦІЙНІ ТЕНДЕНЦІЇ ДІЛОВОГО ТА ДИПЛОМАТИЧНОГО ПРОТОКОЛУ У СФЕРІ ПОСЛУГ
}

\section{INNOVATIVE TRENDS IN BUSINESS AND DIPLOMATIC PROTOCOL IN THE FIELD OF SERVICES}

\author{
Лисюк Тетяна Василівна \\ кандидат педагогічних наук, доцент, \\ Волинський національний університет імені Лесі Українки \\ ORCID: https://orcid.org/0000-0003-1629-9652 \\ Терещук Оксана Степанівна \\ кандидат географрічних наук, доцент, \\ Волинський національний університет імені Лесі Українки \\ ORCID: https://orcid.org/0000-0001-8131-1270 \\ Демчук Ольга Андріївна \\ студентка, \\ Волинський національний університет імені Лесі Українки \\ ORCID: https://orcid.org/0000-0001-5524-4633 \\ Lysiuk Tetiana, Tereshchuk Oksana, Demchuk Olga \\ Lesya Ukrainka Volyn National University
}

\begin{abstract}
У статті розглянуто особливості розвитку інноваційних тенденцій ділового та дипломатичного протоколу у сфері послуг. Проаналізувано значення ділового та дипломатичного протоколу на сучасному етапі розвитку індустрії гостинності. Досліджено управлінську культуру сучасного керівника. Також у статті охарактеризовано вимоги до сучасного керівника сфрери послуг. Визначено перспективи розвитку сфери послуг при ефрективному впроваджені інноваційних технологій у діловому та дипломатичному протоколі. Розроблено пропозиції щодо забезпечення інноваційності ділового та дипломатичного протоколу у сфрері послуг. На сьогодні інновації стають все більш вирішальними для конкурентоспроможності та продуктивності у сорері послуг. Становлення сучасної моделі дипломатії, приводить до висновку, що майбутнє дипломатії багато в чому залежить від того, як надалі буде розвиватися туристичний бізнес, а отже туризм накладає відбиток на роботу та модернізацію ділового та дипломатичного протоколу.

Ключові слова: діловий та дипломатичний протокол, сфрера послуг, інноваційні тенденції, дипломатія.
\end{abstract}

В статье рассмотрены особенности развития инновационных тенденций делового и дипломатического протокола в сфрере услуг. Проанализировано значение делового и дипломатического протокола на современном этапе развития индустрии гостеприимства. Исследовано управленческую культуру современного руководителя. Также в статье охарактеризованы требования к современному руководителю сфреры услуг. Определены перспективы развития сфреры услуг при эфрфективном внедрении инновационных технологий в деловом и дипломатическом протоколе. Разработаны предложения по обеспечению инновационности делового и дипломатического протокола в сорере услуг. Сегодня инновации становятся все более решающими для конкурентоспособности и производительности в сорере услуг. Становление современной модели дипломатии, приводит к выводу. Что будущее дипломатии во многом зависит от того, как в дальнейшем будет развиваться туристический бизнес, а значит туризм накладывает отпечаток на роботу и модернизацию делового и дипломатического протокола.

Ключевые слова: деловой и дипломатический протокол, сорера услуг, инновационные тенденции, дипломатия.

The article considers the peculiarities of the development of innovative trends in businesslike and diplomatic protocol in the field of services. The importance of business and diplomatic protocol at the current stage of development of the hospitality industry was analyzed. Was investigated the management culture of the modern leader. The article also describes the requirements for a modern leader of services. Prospects for the development of the service sector 
with the effective implementation of innovative technologies in business and diplomatic protocol were considered. Proposals have been developed to ensure the innovativeness of business and diplomatic protocol in the field of services. Today, innovation is becoming increasingly crucial for competitiveness and productivity in services. The formation of a modern model of diplomacy leads to the conclusion that the future of diplomacy largely depends on how the tourism business will develop in the future, and therefore tourism has an impact on the work and modernization of business and diplomatic protocol. Analyzing the transformation trends in modern diplomacy, it should be noted that the role of business and diplomatic protocol is very important, because the service sector is developing very rapidly today, and accordingly makes some adjustments to the businesslike protocol process. Innovations in the hospitality industry are related to general processes in society and global problems. Today, a new system of business and diplomatic protocol is being created, the characteristic feature of which is innovation - the ability to update and openness to the new. To develop business and diplomatic protocol in the field of services, we need people with relevant knowledge, creativity and high potential. The source of innovation is a purposeful search for a potential idea in order to promote the institution, where modern business and diplomatic practice only contributes to these innovation processes. Today, the question of the process of modernization of the hospitality industry is becoming increasingly important and this is due to the fact that the hospitality industry is only evolving over time and this innovation is manifested in management, because every tourist manager must make adjustments to modernize business and diplomatic protocol.

Keywords: businesslike and diplomatic protocol. Service industries, innovation trends, diplomacy.

Постановка проблеми. На сьогоднішній день, інновації в індустрії гостинності є двигуном економічного розвитку, появі нових тенденцій і, як наслідок, підвищення якості надаваних послуг й забезпечення конкурентоспроможності у сорері послуг. Впровадження інноваційних технологій у діловому та дипломатичному протоколі вимагає постійного удосконалення, що сприяє більш якісному обслуговуванню гостей.

Традиції і звичаї ділового спілкування та ті цінності, що були актуальними буквально 5 років тому, відбиваються на діловому спілкуванні між персоналом та бізнес-партнерами сьогодні. Саме через не усвідомлення цього, на роботі відбуваються непорозуміння, а іноді й конфрлікти.

Аналіз останніх досліджень та публікацій. На сучасному етапі багато учених опрацьовують теоретичні й практичні питання інноваційної діяльності в ссрері послуг. Серед українських та закордонних науковців досить широко розкривають проблематику та сутність цього питання: Г. Армстронг [1], Ф. Котлер [4], Сидорова А. В. [6], Кучерявенко С. Ю. [5], Шаповалова О. М. [7] та інші. Проте питання інноваційних технологій у сорері послуг, є недостатньо вивченими.

Виділення невирішених раніше частин загальної проблеми. Значна частина науковців у своїх працях акцентує увагу на аналіз конкретних ситуацій у діловому та дипломатичному протоколі. Необхідно дослідити інноваційні технології ділового та дипломатичного протоколу у сорері послуг, як застосовувати ці прийоми на гостях, партнерах та працівниках, 3 метою розвитку закладу та залученню нових потенційних гостей.

Формулювання цілей статті (постановка завдання). Основним завданням даної статті $€$ дослідження інновацій ділового та дипло- матичного протоколу у сфері послуг 3 метою посилення конкурентних позицій і переваг серед інших закладів індустрії гостинності.

Виклад основного матеріалу, дослідження. Інноваційні тенденції ділового та дипломатичного протоколу характеризуються різким зростанням потреб у сорері послуг. Процес модернізації, переходу в управлінській діяльності до сучасних європейських стандартів актуалізує необхідність впровадження інноваційних тенденцій у діловому та дипломатичному протоколі.

На сучасному етапі розвитку інноваційних тенденцій ділового та дипломатичного протоколу відбуваються модернізаційні процеси. Жорстка конкуренція вимагає від сучасного бізнесу нових ідей, товарів, послуг. Ступінь вивчення нового типу поведінки в сфрері послуг дає можливість зрозуміти що лежить в основі сучасних соціально-економічних перетворень.

Сьогодні в розвинених країнах для розвитку нових фрорматів ділового та дипломатичного протоколу застосовують інноваційні керівні рішення по відношенню до персоналу, розвивають інфрормаційні нововведення.

Практика успішних закладів індустрії гостинності показує, що впровадження інновацій у діловому та дипломатичному протоколі збільшує ефрективність і якість процесу обслуговування гостя, прийому іноземних бізнес-партнерів та створення необхідних умов праці для персоналу з метою підвищення його продуктивності.

Одним 3 основних принципів комунікативних процесів у сорері послуг є підтримання нормальних ділових стосунків між працівниками і прагнення уникнути конфрліктних ситуацій.

Значення протоколу на сучасному етапі розвитку індустрії гостинності являє собою вдосконалення затверджених раніше тенденцій ділового та дипломатичного протоколу. Досвід 
показує, що упродовж останніх років лише незначна частина сорери послуг в Україні здійснювала інновації. I для того щоб впроваджувати інноваційну діяльність, потрібна насамперед наявність необхідних внутрішніх і зовнішніх джерел фрінансування. Пріоритетним джерелом інвестування інновацій залишаються власні кошти підприємств та отримані кредити.

Однак не зважаючи на незначні масштаби інноваційної діяльності у діловому та дипломатичному протоколі, її позитивний вплив на загальні показники роботи підприємств сфери послуг є очевидними та безперечними.

Сучасна міжнародна протокольна практика свідчить про тенденцію до організації скромних прийомів, які б виключали елементи непотрібної пишності, надмірної кількості спиртного або дорогих страв. Бажано, щоб в меню прийомів враховувалися як національний колорит своєї країни, так і національні та релігійні особливості країни перебування. Вкрай некоректно пропонувати мусульманам свинину в закладах харчування [2].

На сьогодні перспективи розвитку сорери послуг при ефективному впроваджені інновацій у протоколі в значній мірі залежить від розвитку сучасних тенденцій у світі. Індустрія гостинності повинна підтримувати розвиток інноваційних тенденцій у діловому та дипломатичному протоколі, адже реалізація сучасних видів протоколу, створює умови для розширення різноманітних послуг, посилює конкурентні позиції, дає досить швидкий ефект в отримані прибутку та допомагає створити сприятливі умови для фрункціонування підприємств сфрери послуг.

Роль культурного чинника у вирішенні сучасних проблем управління туристичним підприємством постійно зростає. Наявність у керівника сучасного рівня знань протоколу є необхідністю, адже в нинішніх умовах надзвичайної актуальності набуває проблема поціновування людських ресурсів у сорері публічного управління.

Саме тому елементами сучасної культури ділового та дипломатичного протоколу як органічної складової загальної культури керівника мають стати [3, с. 6]:

- сучасні управлінські знання, вміння, навички, професійність, компетентність, профресіоналізм;

- організаційні, передусім управлінські відносини, в яких матеріалізуються знання керівника-профресіонала 3 організації міжособистісної взаємодії з підлеглими;

- управлінська діяльність, творчий характер який дає змогу перетворювати знання й цінності на стійкі риси особистості.
- людинознавчі знання, що визначають якість організованої керівником міжособистісної взаємодії з практичним застосуванням положень концепції активного туристичного підприємства.

Від розвитку ділового та дипломатичного протоколу залежить ефективність очолюваного керівником підприємства індустрії гостинності. Необхідно зазначити, що нині надзвичайної пріоритетності набувають дослідження якісних характеристик сучасного керівника як організатора колективної роботи підлеглих співробітників. Так, наприклад, англійські спеціалісти управління М. Вудкок та Д. Френсіс визначають одинадцять основних якостей, необхідних керівникові для здійснення функції есрективного управління підлеглими [3, с. 7]:

1. Здатність керувати собою.

2. Наявність особистих цілей.

3. Чіткість особистих цілей.

4. Спирання на постійне особисте зростання.

5. Навички вирішування проблем.

6. Винахідливість та здатність до інновацій.

7. Висока здатність впливати на оточуючих.

8. Здатність керувати.

9. Знання сучасних управлінських підходів.

10. Вміння навчати підлеглих.

11. Здатність розвивати та фрормувати есрективні робочі групи.

Від розвитку ділового та дипломатичного протоколу залежить ефективність очолюваного керівником підприємства індустрії гостинності. Зрозуміло, що недостатній рівень профресіоналізму у керівників підприємств індустрії гостинності гальмує розвиток інноваційної діяльності ділового та дипломатичного протоколу у сорері послуг. Тож не дивно, що недостатньо підготовленому, некомпетентному керівнику, який не володіє навіть традиційними знаннями ділового та дипломатичного протоколу, важко засвоїти перш за все сучасні елементи протоколу.

Варто зазначити, що сучасний розвиток суспільства сприяє модернізації ділових та дипломатичних норм у сорері послуг.

На сьогодні, відбувається перехід від традиційних методів управління до сучасних (табл. 1).

На сьогодні перед закладами індустрії гостинності стоїть завдання щодо врахування у формуванні і реалізації сучасних протокольних норм, технологій вирішення робочих питань, форм і методів управління персоналом у критичних ситуаціях.

Перспективи розвитку сфери послуг при есрективному впроваджені інноваційних технологій у діловому та дипломатичному прото- 
Таблиця 1

\section{Управлінські методи керівництва підлеглими}

\begin{tabular}{|l|l|}
\hline \multicolumn{1}{|c|}{ Традиційний } & \multicolumn{1}{c|}{ Сучасний } \\
\hline Застосовує критику & Використовує похвалу \\
\hline Віддає накази та вказівки & Визначає цілі \\
\hline $\begin{array}{l}\text { Розглядає зусилля підлеглих } \\
\text { як щось само собою зрозуміле }\end{array}$ & $\begin{array}{l}\text { Хвалить підлеглих за докладені зусилля } \\
\text { та отримані результати }\end{array}$ \\
\hline Акцентує увагу на виконанні завдань & $\begin{array}{l}\text { Акцентує увагу на заохочуванні якісного } \\
\text { виконання завдань }\end{array}$ \\
\hline Підлеглий повинен бути весь час на своєму місці & Стимулює підвищення есективності, якості праці \\
\hline Манера поведінки - підкреслено офіційна & Манера поведінки - дружня \\
\hline
\end{tabular}

Джерело: розроблено авторами на основі [3, с. 8]

колі очевидні, адже сорера послуг є тим динамічним сектором економіки, де попит постійно зростає, створюючи потенціал для розвитку інноваційних технологій у діловому та дипломатичному протоколі.

Висновки. Загалом слід зазначити, що інноваційні тенденції торкнулися найважливіших моментів у ссрері послуг.
Нові тенденції свідчать про те, що значні недоліки та прогалини в управлінні персоналом на сучасному етапі розвитку, зумовлені швидкими змінами як зовнішнього, так і внутрішнього середовища, у якому фрігура професійного керівника туристичного підприємства залишатиметься необхідною для забезпечення стабільного розвитку туристичного підприємства.

\section{СПИСОК ВИКОРИСТАНИХ ДЖЕРЕЛ:}

1. Армстронг Г., Сондерс Д., Вонг В., Котлер Ф. Основы маркетинга. 4-е европейское издание. Москва : ООО «ИД Вильямс», 2007. 1200 с.

2. Дипломатичний протокол // Вікіпедія: вільна енциклопедія. URL: https://uk.wikipedia.org/wiki/\%D0\%94\% D0\%B8\%D0\%BF\%D0\%BB\%D0\%BE\%D0\%BC\%D0\%B0\%D1\%82\%D0\%B8\%D1\%87\%D0\%BD\%D0\%B8\%D0\% B9_\%D0\%BF\%D1\%80\%D0\%BE\%D1\%82\%D0\%BE\%D0\%BA\%D0\%BE\%D0\%BB (дата звернення: 05.08.2021).

3. Комунікації в публічному управлінні: аспекти організаційної культури та ділового спілкування : навч. посіб. / уклад. : Гошовська В.А. та ін. Київ : К.І.С., 2016. 130 с. (Серія «Бібліотечка лідера місцевого самоврядування»).

4. Котлер Ф. Основи маркетинга / пер. с англ. общ. ред. и вступ. ст. Е.М. Пеньковой. Москва : Прогресс, 1990. $410 \mathrm{c}$.

5. Кучерявенко С.Ю. Сутність інноваційно-інвестиційного розвитку підприємств ссрери послуг. Київ : Знання, 2012. С. 4-47.

6. Сидорова А.В. Экономико-статистические методы в управлении сфрерой услуг. Донецк : ДонНУ, 2002. 240 с.

7. Шаповалова О.М. Інноваційний розвиток підприємств сорери послуг: туризму. Вісник східноукраїнського національного університету імені Володимира Даля. 2013. № 4(193) Ч. 2. С. 241-246.

\section{REFERENCES:}

1. Armstrong G., Sonders D., Vong V. and Kotler F. (2007) Osnovu marketinga [Marketing bases]. Moscow: OOO "ID Viliams". (in Russian)

2. Dyplomatychnyi protocol [Diplomatic protocol]. Available at: https://uk.wikipedia.org/wiki/\%D0\%94\%D0\% B8\%D0\%BF\%D0\%BB\%D0\%BE\%D0\%BC\%D0\%B0\%D1\%82\%D0\%B8\%D1\%87\%D0\%BD\%D0\%B8\%D0\%B9_\% D0\%BF\%D1\%80\%D0\%BE\%D1\%82\%D0\%BE\%D0\%BA\%D0\%BE\%D0\%BB (accessed 05 August 2021).

3. Hoshovska A.V. (2016) Komunikatsii v publichnomu upravlinni: aspekty orhanizatsiinoi kultury ta dilovoho spilkuvannia [Communications in public administration: aspects of organizational culture and business communication]. Kyiv: K.I.S. (in Ukrainian)

4. Kotler F. (1990) Osnovu marketinga [Marketing bases]. Moscow: Progress. (in Russian)

5. Kycheriavenko S.ly. (2012) Sytnist innovatsiino-investutsiinogo rozvutky pidpruemstv sferu poslyg [The essence of innovation and investment development service industries]. Kyiv: Znannia. (in Ukrainian)

6. Sidorova A.V. (2002) Economico-statisticheskie metodu $v$ ypravlenii sferoi yslyg [Economic and statistical methods in the management of the services sector]. Donetsk: DonNY. (in Ukrainian)

7. Shapovalova O.M. (2013) "Innovative development of service industries: tourism". Newsletter East Ukrainian National University named after Volodymyr Dahl, no. 4(193), pp. 241-246. (in Ukrainian) 